\title{
PHAEOGRAPHIS PATAGONICA (GRAPHIDACEAE, ASCOMYCOTA) NEW TO ARGENTINA
}

\section{PHAEOGRAPHIS PATAGONICA (GRAPHIDACEAE, ASCOMYCOTA), NUEVA CITA PARA LA ARGENTINA}

\author{
María Inés Messuti ${ }^{1} \&$ Patricia L. Codesal ${ }^{2}$ \\ ${ }^{1}$ Instituto de Investigaciones en Biodiversidad y Medioambiente (INIBIOMA CONICET-UNComahue), Quintral \\ 1250, R8400 FRF, S.C. de Bariloche, Río Negro, Argentina; ${ }^{2}$ Facultad de Ciencias Naturales, Universidad Nacional \\ de la Patagonia San Juan Bosco, Sarmiento 849, 9200 Esquel, Chubut, Argentina. \\ mmessuti@crub.uncoma.edu.ar
}

\section{RESUMEN}

Phaeographis patagonica Zahlbr., es registrada por primera vez para la Argentina. Los especímenes aquí citados fueron coleccionados en la región del bosque templado tipo valdiviano o selva valdiviana al sudoeste del país. Se presenta una breve descripción, hábitat, distribución y una clave de las especies presentes en la Argentina.

During studies of the microlichens of cool temperate areas (higrophylous forest) in southwestern Argentina, a collection of lichens made in summer of 2006 and the spring of 2007 by the second author in the Parque Nacional Los Alerces, Provincia de Chubut (42 $\left.{ }^{\circ} 51^{\prime} \mathrm{S} ; 71^{\circ} 51^{\prime} \mathrm{W}\right)$, disclosed an interesting and rare corticolous species, Phaeographis patagonica Zahlbr., not hitherto listed in the recent Argentine lichen=checklists (Calvelo \& Liberatore 2002, Feuerer 2009) or, to our knowledge, in any other publication dealing with the lichen flora of Argentina. The genus Phaeographis is practically unknown in Argentina. The new report presented here, together with Phaeographis lobata (Eschw.) Müll. Arg. reported from northeast Argentina (Osorio \& Ferraro 1975), are the only two species of the genus recognized for this country. The aim of this communication is to present a description of the poorly known species $P$. patagonica and to provide information on its distribution and habitat in Argentina.

THE SPECIES

Phaeographis patagonica Zahlbr., Ann. Mycol. 6: 129 (1908); Type: "Westpatagonien: auf Baumrinden bei Puerto Bueno", majo 3? 1896, Dusén No. 56 (W not seen-holotype) (fide Zahlbruckner 1908, Staiger 2002).

Phaeographis patagonica var. holoplaca Zahlbr., Rev. Chil. Hist. Nat. 37: 166 (1933) nomen nudum; Type: sine loco (W not seen-holotype) (fide Zahlbruckner 1933).

Thallus corticolous, epiphloeodal, crustose, rimose, greenish to greenish-white, thin, ca. 50-100 $\mu \mathrm{m}$, surface smooth, dull to slightly shiny. Ecorticated or with a cortex formed by prosoplectenchimatous periclinal hyphae. Apothecia lirelliform, conspicuous, numerous, scattered or crowed, sessile, straight, sinuous or irregular, simple or sometimes branched, conspicuously open, with a well defined thin and whitish thalline margin, 0.8$3 \mathrm{~mm}$ long, 0.4-0.7 mm wide. Discs brown-black to dark brown, sometimes weakly pruinose, proper margin inconspicuous, black. Proper exciple carbonized laterally and basally, with big crystals near the base. Epihymenium brown, ca. 6-18 $\mu \mathrm{m}$ tall. Hymenium inspersed with oil drops, I-, 120$150 \mu \mathrm{m}$ tall. Paraphyses somewhat anastomosed, branched at the apical part, brown, ca. $1.5 \mu \mathrm{m}$ diam. Hypothecium at the base carbonized or not. 
Gayana Bot. 66(2), 2009

Asci claviform. Ascospores 8 per ascus, uni to biseriate, rounded ellipsoid to oblong, transversally septate (linear lenticular), pale brown to brown, 4-6 locular, I+ reddish brown, 18-30 (-34) x 6-10 $\mu \mathrm{m}$.

Chemistry: No lichen compounds detected.

Habitat: In Argentina, $P$. patagonica is a rare species growing on the bark of the endemic southern South American tree, Drimys winteri J.R.Forst. et G.Forst. close to the stream Los Alerces. The area where the species occurs is an ingression of the Valdivian rainforest on the eastern side of the Andean range in the western region of Southern Argentina. The climate in this area is very humid, with mean annual precipitation of $3000 \mathrm{~mm}$ and an annual mean ambient temperature of $8{ }^{\circ} \mathrm{C}$.

Distribution: Very few members of the family Graphidaceae are found in the southern part of South America. Although the genus Phaeographis has a predominantly tropical to subtropical distribution (Archer 2006) some species such $P$. patagonica occur in temperate areas. Phaeographis patagonica has so far been cited as endemic to Chile [Región de Magallanes y Antártica Chilena or XII Región (W holotype,
MSC0010784 and MAF-Lich 507-1)]. Now it is recorded for the first time to Argentina, where it was collected in a single locality in Provincia de Chubut in a cool temperate area (Valdivian rainforest vegetation) near the border with Chile (X Región). This is also an extension of the northern range of distribution of the species, restricted till now to the western range of Los Andes, in Magallanes Province, Chile.

Distinguishing FEATURES: The species is characterized by excipular labia and proper margins poorly developed and weakly carbonized, hymenium I-, mature ascospores brownish, and transversally septate with 4-6 locules, I+ redish brown (? immature rarely I-) and no lichen compounds detected. The combination of the above characters separate $P$. patagonica from the other species registered for Argentina, P. lobata, a widely distributed tropical species (Staiger 2002, Archer 2006).

Specimens exAmined. ARGENTINA, Provincia de Chubut, Parque Nacional Los Alerces, desembocadura del río Los Alerces, 02-XII2006, P. Codesal (BCRU 04879); Brazo sur Lago Menéndez, desembocadura río Los Alerces, 02XII-2006, P. Codesal (BCRU 04880).

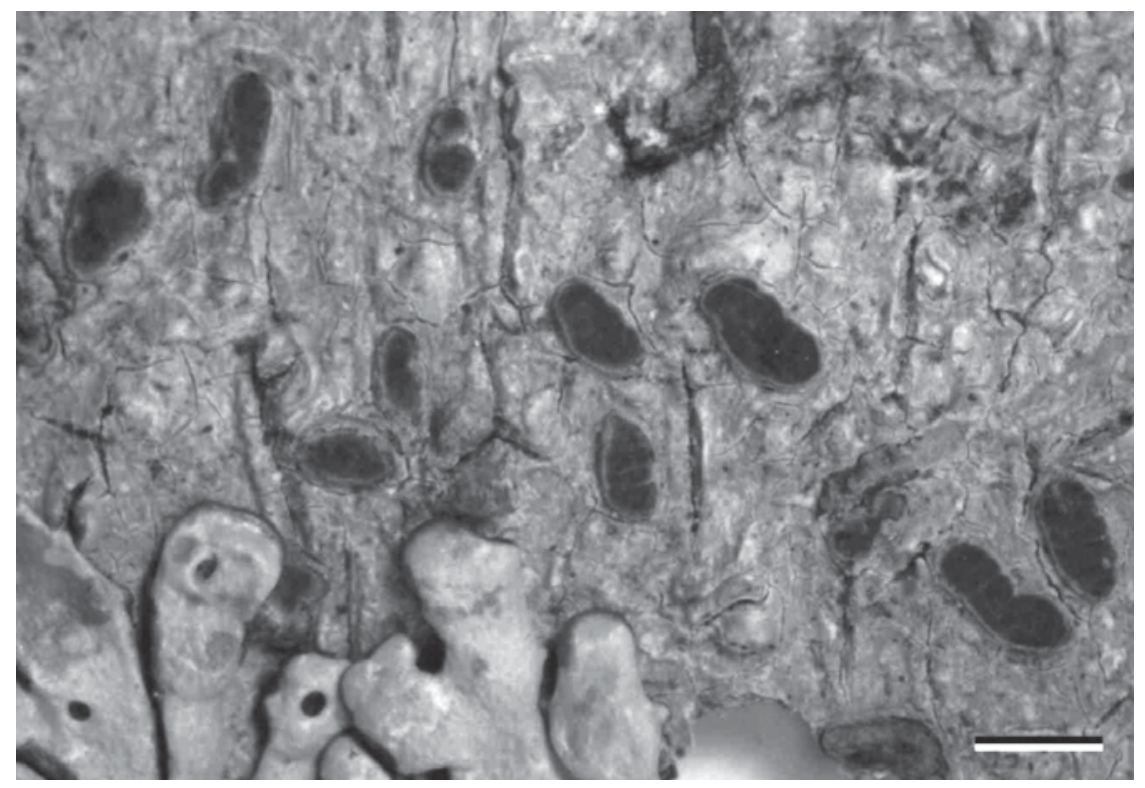

Figure. 1. Phaeographis patagonica, habitus of BCRU 04879 specimen. Scale $=2 \mathrm{~mm}$.

FiguRA 1. Phaeographis patagonica, hábito del espécimen BCRU 04879. Escala $=2 \mathrm{~mm}$. 
Phaeographis patagonica, new to Argentina: Messuti, M.I. \& P.L. Codesal

Key to the Known species of PhaEographis in Argentina

1. Proper exciple apically carbonized; ascospores $27-47 \mu \mathrm{m}$ long, 6-11 locular

P. lobata

1 '. Proper exciple laterally carbonized; ascospores 18-30 (-34) $\mu \mathrm{m}$ long, 4-6 locular P. patagonica

\section{ACKNOWLEDGEMENTS}

Financial support by Universidad Nacional del Comahue and CONICET is appreciated. We are grateful to Dr. Camus, Dr. Feuerer, Dr. Lumbsch, Mr. Zavala Fernández and Mr. R. Vargas, for the assistance provided for obtain old bibliographic references.

\section{REFERENCES}

ArCHER, A.W. 2006. The lichen family Graphidaceae in Australia. Bibliotheca Lichenologica 94: 1-191.

Calvelo, S. \& S. Liberatore. 2002. Catálogo de los
Líquenes de la Argentina. Kurtziana 29(2): 7-170.

FEUERER, T. (ed.) 2009 Checklists of lichens and lichenicolous fungi. URL: http: //www.checklist. de, Version 1 February 2009.

Osorio, H.S. \& L.I. Ferraro. 1975. Contribution to the lichen flora of Argentina. VII. New and noteworthy records form the Province of Corrientes. Comunicaciones Botánicas del Museo de Historia Natural de Montevideo 57(4): 1-4.

Staiger, B. 2002. Die Flechtengfamilie Graphidaceae. Studien in Richtung einer natürlicheren Gliederung. Bibliotheca Lichenologica 85: 1-526.

Zahlbruckner, A. 1908. Neue Flechten. IV. Annales Mycologici 6: 129-134.

ZahlBruCKNER, A. 1933. Los líquenes del herbario del Museo Nacional de Santiago de Chile. Revista Chilena de Historia Natural 37: 165-170. 